MARTA TUTKO

Jagiellonian University in Kraków, Poland

\title{
Academic Entrepreneurship in the Development Strategies of Polish Universities
}

\begin{abstract}
This article addresses the issue of academic entrepreneurship, broadly understood as: (1) the process of establishing companies, (2) university entrepreneurship, (3) development of educational programs and entrepreneurial attitudes among students and academics, (4) creating institutions and programs that support setting up of companies, (5) intellectual property management and (6) entrepreneurial university management (Banerski et al., 2009). The goal is to examine the presence of academic entrepreneurship in the development strategies of eighteen Polish public universities. This study uses the content analysis method and is a part of strategic research. To answer the research question, the universities' development strategies were analysed and in particular mission statements, strategic and operational goals, activities/tasks. Based on the research, it can be concluded that university authorities do not perceive academic entrepreneurship as a goal of the utmost importance and only to a small extent see the need to develop this concept by taking it into account in development strategies.
\end{abstract}

Keywords: academic entrepreneurship; development strategy; higher education; Poland; strategic research; university.

Received: 25 September 2019

Accepted: 23 February 2020

\section{Suggested citation:}

Tutko, M. (2020). Academic Entrepreneurship in the Development Strategies of Polish Universities. Przedsiębiorczość - Edukacja [Entrepreneurship - Education], 16(1), 132-143. doi: 10.24917 /20833296.161.11

\section{Introduction}

There are many theories, concepts and models that connect entrepreneurship with economic growth or, more broadly, with social and economic development (Carlsson et al., 2009; Carree et al., 2014; Płaziak, Rachwał, 2015; Wach, 2015). It is considered as a "key competence for growth, employment and personal fulfilment" (European Commission 
2006: 4). For this reason, entrepreneurship has become an increasingly interesting subject for researchers. As a research domain, it has been experiencing a boom for several decades.

Academic entrepreneurship is a specific type of entrepreneurship, "focusing on the creative attitudes of the academic community and the use of their effects in economic practice" (Poznańska, 2014: 166; author's translation). The development of academic entrepreneurship also brings benefits to the national and global economy and contributes to increasing its competitiveness (Poznańska, 2014).

Consideration in this article has been narrowed to the subject of academic entrepreneurship and its goal is to examine its presence in the development strategies of Polish public universities. The research was conducted in the first half of 2019. Eighteen university development strategies were analysed in which records regarding entrepreneurship were sought. This study has used the content analysis method.

The paper is organised into five sections. It starts with bringing the reader closer to the issues of academic entrepreneurship and strategies in higher education institutions. Then, the research method and findings are presented, followed by the conclusions and a summary.

\section{Academic entrepreneurship}

Academic entrepreneurship is defined in many ways. Initially, this concept was limited to the creation of spin-off and spin-out companies. However, nowadays it is understood more broadly and covers any activity at the university related to the offering and selling of know-how (Poznańska, 2014). According to another definition, it is an "activity in the field of business education and practical support for new companies based on the know-how of those involved in academic research" (Banerski et al., 2009: 6; author's translation).

In the literature, some problems of interpretation regarding the concept and scope of academic entrepreneurship are found. In Anglo-Saxon countries, this concept is identified with (1) the process of establishing companies (spin-offs or spin-outs) run by academic staff and students, and (2) university entrepreneurship, understood as all the situations in which the university offers and sells 'know-how' (Banerski et al., 2009). The approach here refers to the definition of Poznańska (2014).

In Poland, as in other countries of Continental Europe, the phenomenon is perceived more broadly as (1) the development of educational programs, promotion and development of entrepreneurial attitudes among students and academics, (2) creating institutions and programs that support setting up companies by students and academics, (3) intellectual property management, preparation of rules and regulations for the commercialisation of research, and (4) entrepreneurial university management, which is a specific enterprise with high social usefulness that can and should be well managed. This understanding of academic entrepreneurship is largely consistent with the definition by G. Banerski et al. (2009: 6). K. Brendzel-Skowera (2014) proposes a similar approach. In her opinion, academic entrepreneurship should also be defined in a broader sense. This means that it refers not only to the creation of spin-outs/spin-offs, but also the activities supporting the cooperation between 'know-how' and the economy. At the same time, it should be understood as the entrepreneurship of the university itself. 
Academic entrepreneurship in Poland is legally established in the Law on Higher Education, which states that "higher education institutions cooperate with the socio-economic environment, in particular in the field of conducting academic research and development work for business entities, in separate forms of activity, including the establishment of a special-purpose company" (Ustawa z dnia 27 lipca 2005 Prawo o szkolnictwie wyższym; author's translation).

Considering the above approaches, for the purposes of this article, a broad definition of the concept has been adopted covering many activities of the university. In particular, academic entrepreneurship is understood as:

- the process of establishing companies (spin-offs or spin-outs),

- university entrepreneurship,

- development of educational programs and entrepreneurial attitudes among students and academics,

- creating institutions and programs that support setting up companies,

- intellectual property management,

- entrepreneurial university management.

Undertaking an attempt to assess the level of academic entrepreneurship in Poland, it should be noted that higher education institutions are still at an early stage of shaping a model (Poznańska, 2014). They are still perceived as entities not particularly interested in the fact that students and academics can develop their own businesses and the policy on academic entrepreneurship depends on the attitude of the group predominant in the university authorities (Banerski et al., 2009).

\section{Strategies in Polish higher education}

"Strategy" is a word with many meanings and an ambiguous concept, therefore it is impossible to give one commonly accepted definition. In the literature, there are many definitions of strategies understood as a plan, a set of intentions and objectives, a model, the position of the organisation, the best use of resources and organisation skills, a way to solve a problem, the use of opportunities in the external environment or responding to changes (Zakrzewska-Bielawska, 2011).

For the purposes of this study, the definition of "strategy" formulated by Stoner, which seems to be the most appropriate to conditions for the functioning of a university (Wawak, 2014), was adopted. According to it, "strategy" is a broad program of setting and achieving the organisation's goals and responding to the external environment (Stoner, Freeman, Gilbert, 2001).

The goals of an organisation are defined as the desired future state of affairs (Vroom, 1960). They are subject to hierarchy and are defined at three levels: strategic, tactical and operational (Griffin, 2014). The strategic level is the most important; its goals are very general and few and most often refer to its mission, which is a general term describing the fundamental reason for an organisation's existence. Tactical objectives are set at the medium organisational level which focuses on the manner of operationalisation of activities that are necessary to achieve strategic objectives, while operational objectives are set at the lowest organisational level.

Development strategies are created for both individual organisations (universities) and for entire industries, such as for the higher education sector. In Poland, at the 
beginning of 2010, two competitive strategies for the development of higher education for 2010-2020 were published: (1) Strategy for the development of higher education 20102020: Environmental report developed by a consortium of the Conference of Rectors of Academic Schools in Poland, the Conference of Rectors of Public Vocational Schools and the Polish Rectors' Foundation; and (2) Strategy for the development of higher education in Poland by 2020 developed by Ernst \& Young Business Advisory and the Institute for Market Economics. The first one was developed on the initiative of the academic community and will be briefly described in this article.

In the Strategy for the development of higher education 2010-2020: Environmental report the main functional areas in higher education were distinguished: educational activities, academic and R \& D activities, as well as cooperation between the university and the external environment. The strategy presents seven strategic objectives (Table 1), two in each of the functional areas, and one strategic goal (Woźnicki, 2010).

Table 1. Strategic objectives in the Strategy for the development of higher education 2010-2020: Environmental report

\begin{tabular}{|c|l|}
\cline { 2 - 3 } \multicolumn{1}{c|}{} & \multicolumn{1}{c|}{ Strategic objectives } \\
\hline 1. & Adapting the education system to changing social needs \\
\hline 2. & Improving the quality of education in a mass-market \\
\hline 3. & Increasing the productivity of higher education R \& D \\
\hline 4. & $\begin{array}{l}\text { Increasing the effectiveness of the research activity of a higher education academic } \\
\text { employee }\end{array}$ \\
\hline 5. & Expanding the educational role of the university towards society \\
\hline 6. & $\begin{array}{l}\text { Increasing the internationalisation of Polish higher education and improving } \\
\text { the position of Polish universities on an international scale }\end{array}$ \\
\hline 7 & Improving systemic solutions for higher education \\
\hline
\end{tabular}

Source: based on Strategia rozwoju... (2009)

As part of strategic objective no 4 (Table 1), the operational objective: "Improvement of the system supporting academic and research activities and development at universities" is set out. The following two actions are indicated: (1) introducing incentives for active involvement of organisational units and their employees in the development of entrepreneurship and innovation as well as extending the scope of impact measures to university technology transfer centres and business incubators; and (2) dissemination of education in the field of "entrepreneurship for innovation" (Strategia rozwoju..., 2009). It can, therefore, be concluded that the issues of academic entrepreneurship are present in the Strategy for the development of higher education 2010-2020: Environmental report, prepared for the entire higher education sector in Poland.

It is not easy to find information on larger-scale research aimed at analysing university development strategies in Poland (Dziedziczak-Foltyn, 2011) which indicates an existing research gap in this area.

Research conducted so far (Piotrowska-Piątek, 2015) shows that Polish higher education institutions consider the definition of strategic goals as a key element of their strategies. At the same time, only half of the analysed strategies indicate ways to achieve these objectives, and indicators monitoring their implementation are defined even more rarely. 
The issues discussed in this study concern academic entrepreneurship. In particular, Polish university development strategies, created in 2010-2012, were analysed. References to academic entrepreneurship were sought in these documents.

This approach is as a part of strategic research. Methods of gathering materials for empirical research, the most useful and most frequently used in strategic research, include surveys, analysis of statistical and reporting material, as well as content analysis of press and internet information (Romanowska, 2012). This study uses the content analysis method which falls within qualitative research.

W. Czakon (2015) notes that interpretative (qualitative) research is aimed at understanding a selected part of reality. Understanding means how participants experience it in reality, how they participate in it, how they shape and interpret it (Czakon, 2015). Silverman (2008) adds that qualitative research allows questions of "how?", "why?", "in what way?" to be answered, and that it is of an explanatory character.

In the case of qualitative research, there are many possibilities concerning the research procedure, but most often it begins with the determination of the research issue (Czernek, 2015). This article raises the following research question:

In what way are academic entrepreneurship issues present in the development strategies of Polish universities?

Apart from this question, it is important to find answers to others, i.e. how academic entrepreneurship issues are presented in university mission statements as well as at the levels of the hierarchy of goals: strategic and operational goals and activities/tasks defined in the strategies. It is worth adding at this point that these are the types of goals presented in Polish university strategies (there are no goals that could be called "tactical").

In the academic year 2017/2018, there were 397 higher education institutions in Poland, including 130 public ones (Szkoły wyższe $i$ ich finanse $w 2017$ r., 2018). This group includes the following types (Szkoły wyższe $i$ ich finanse $w 2017$ r., 2018): universities, technical universities, agricultural academies (including agricultural universities), academies of economics (including universities of economics), higher teacher education schools (including pedagogical universities), medical universities, maritime universities, physical academies, theological academies, fine arts academies, and other higher education institutions (including public higher vocational schools). There were two main categories: university-type and non-university institutions. The subjects of this research were all public universities (university-type institutions) operating in Poland. The focus was on these universities because they have a similar specificity (e.g. an organisational structure based on faculties), and the author was looking for a group of universities that would be relatively homogeneous and not embedded in a single academic area.

At the first stage of the study, the university websites were examined in order to obtain their development strategies. Then the content of these documents was analysed. Academic entrepreneurship was searched for by using the following key terms: 'academic entrepreneurship', 'university entrepreneurship', 'entrepreneurship', 'entrepreneurial attitudes', 'entrepreneurial university', 'enterprise', 'company', 'spin-off, 'spin-out', 'intellectual property' and others related. 


\section{Research findings}

To answer the research question, the universities' mission statements and goals in the development strategies, were examined.

\section{University mission statements}

Only in the case of three universities their statements contained direct records to academic entrepreneurship:

- "The University prepares highly qualified, entrepreneurial graduates full of initiative and creativity for professional work" (Adam Mickiewicz University in Poznań),

- "The teacher-student relationship builds student independence, giving a chance to [...] develop entrepreneurship" (University of Opole),

- "The University [...] is a culture-creating, entrepreneurial and modern academic centre" (University of Rzeszów).

Appeals to entrepreneurship in university mission statements are rare. Academic entrepreneurship is understood as university entrepreneurship (University of Rzeszów) and as the development of educational programs and entrepreneurial attitudes among students and academics (Adam Mickiewicz University in Poznań, University of Opole).

\section{University goals in development strategies}

First, it should be emphasised that academic entrepreneurship issues are present in nine of 18 university strategies that were analysed. The concept is found in those nine universities' goals in many ways, as presented in Table 2.

Table 2. Academic entrepreneurship in the university strategic goals

\begin{tabular}{|l|l|l|l|}
\hline University & \multicolumn{1}{|c|}{ Strategic goals } & \multicolumn{1}{|c|}{ Operational goals } & \multicolumn{1}{c|}{ Activities/Tasks } \\
\hline \multirow{2}{*}{$\begin{array}{l}\text { World-class academic } \\
\text { research }\end{array}$} & $\begin{array}{l}\text { Implementation of the } \\
\text { system of protection } \\
\text { and use of intellectual } \\
\text { property }\end{array}$ & \\
\cline { 2 - 4 } & $\begin{array}{l}\text { University open to the } \\
\text { external environment }\end{array}$ & $\begin{array}{l}\text { Opening the university } \\
\text { to the needs of } \\
\text { a knowledge-based } \\
\text { economy }\end{array}$ & $\begin{array}{l}\text { Supporting academic } \\
\text { entrepreneurship }\end{array}$ \\
\hline \multirow{2}{*}{} & $\begin{array}{l}\text { Science - the foundation } \\
\text { of the University }\end{array}$ & $\begin{array}{l}\text { Implementing solutions } \\
\text { for the protection } \\
\text { and use of intellectual } \\
\text { property }\end{array}$ & \\
\cline { 2 - 4 } & $\begin{array}{l}\text { University open to the } \\
\text { external environment }\end{array}$ & $\begin{array}{l}\text { Opening of the } \\
\text { university to the needs } \\
\text { of the knowledge-based } \\
\text { economy }\end{array}$ & $\begin{array}{l}\text { Supporting academic } \\
\text { entrepreneurship }\end{array}$ \\
\cline { 3 - 4 } & $\begin{array}{l}\text { Modernisation of the } \\
\text { university infrastructure }\end{array}$ & $\begin{array}{l}\text { Infrastructure } \\
\text { development: } \\
\text { Entrepreneurship } \\
\text { and Business Center }\end{array}$ \\
\hline
\end{tabular}




\begin{tabular}{|c|c|c|c|}
\hline \multirow{2}{*}{ 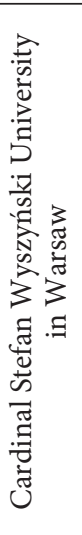 } & Innovative research & $\begin{array}{l}\text { Instruments for } \\
\text { organising and } \\
\text { supporting academic } \\
\text { research }\end{array}$ & $\begin{array}{l}\text { Establishment of an } \\
\text { entrepreneurship } \\
\text { incubator and protection } \\
\text { of intellectual property } \\
\text { rights of academics and } \\
\text { the university }\end{array}$ \\
\hline & $\begin{array}{l}\text { Cooperation the } \\
\text { business, social } \\
\text { and institutional } \\
\text { environment }\end{array}$ & $\begin{array}{l}\text { Cooperation with } \\
\text { the business, social } \\
\text { and institutional } \\
\text { environment }\end{array}$ & $\begin{array}{l}\text { Creating and } \\
\text { commercialising } \\
\text { innovation, shaping } \\
\text { education programs that } \\
\text { take into account the } \\
\text { needs of employers, and } \\
\text { promoting creativity and } \\
\text { entrepreneurship among } \\
\text { students }\end{array}$ \\
\hline \multirow{2}{*}{ 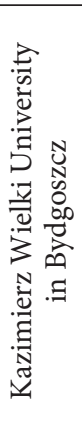 } & $\begin{array}{l}\text { Ensuring the highest } \\
\text { quality of education }\end{array}$ & $\begin{array}{l}\text { Improving the learning } \\
\text { process }\end{array}$ & $\begin{array}{l}\text { Raising didactic } \\
\text { competences of } \\
\text { academic teachers } \\
\text { and shaping attitudes } \\
\text { (including intellectual } \\
\text { property protection) }\end{array}$ \\
\hline & $\begin{array}{l}\text { Effective cooperation } \\
\text { with the socio-economic } \\
\text { environment }\end{array}$ & $\begin{array}{l}\text { Cooperation with } \\
\text { business entities }\end{array}$ & $\begin{array}{l}\text { Development and } \\
\text { implementation of } \\
\text { a support system in } \\
\text { entrepreneurial activities } \\
\text { for researchers and } \\
\text { students }\end{array}$ \\
\hline \multirow{2}{*}{ 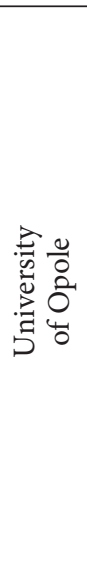 } & $\begin{array}{l}\text { Improving the academic } \\
\text { position of the university } \\
\text { in the national and } \\
\text { international network } \\
\text { of research centres }\end{array}$ & $\begin{array}{l}\text { Development and } \\
\text { implementation } \\
\text { of an intellectual } \\
\text { property protection } \\
\text { system, copyright } \\
\text { management as well as } \\
\text { commercialisation and } \\
\text { knowledge transfer }\end{array}$ & - \\
\hline & $\begin{array}{l}\text { Improving the position } \\
\text { of the university in } \\
\text { the national and } \\
\text { international network } \\
\text { of training centres }\end{array}$ & $\begin{array}{l}\text { Empowering students, } \\
\text { creating active and } \\
\text { entrepreneurial attitudes }\end{array}$ & $\begin{array}{l}\text { Supporting student } \\
\text { entrepreneurship } \\
\text { by the Academic } \\
\text { Entrepreneurship } \\
\text { Incubator and training } \\
\text { entrepreneurial } \\
\text { competences among } \\
\text { students }\end{array}$ \\
\hline \multirow{2}{*}{ 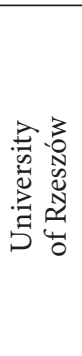 } & $\begin{array}{l}\text { A high level of education } \\
\text { consistent with the } \\
\text { academic profile } \\
\text { adapted to the needs } \\
\text { and expectations of the } \\
\text { labour market }\end{array}$ & $\begin{array}{l}\text { Creating active and } \\
\text { entrepreneurial attitudes } \\
\text { of students }\end{array}$ & $\begin{array}{l}\text { Introduction of forms } \\
\text { of education developing } \\
\text { entrepreneurship and } \\
\text { preparing for self- } \\
\text { employment }\end{array}$ \\
\hline & $\begin{array}{l}\text { High academic position } \\
\text { of the university built on } \\
\text { the basis of modern staff } \\
\text { and infrastructure }\end{array}$ & $\begin{array}{l}\text { Increase in academic } \\
\text { research carried } \\
\text { out at national and } \\
\text { international level }\end{array}$ & $\begin{array}{l}\text { Introduction of an } \\
\text { intellectual property } \\
\text { protection system }\end{array}$ \\
\hline
\end{tabular}




\begin{tabular}{|c|c|c|c|}
\hline \multirow[t]{2}{*}{ 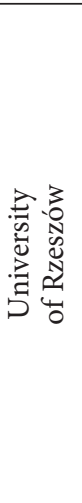 } & $\begin{array}{l}\text { Professional and } \\
\text { effective relations with } \\
\text { the external environment }\end{array}$ & $\begin{array}{l}\text { Intensified cooperation } \\
\text { with external } \\
\text { stakeholders }\end{array}$ & $\begin{array}{l}\text { Activation of all units } \\
\text { towards the creation } \\
\text { of science-business } \\
\text { partnerships for the } \\
\text { commercialisation } \\
\text { of research results } \\
\text { (consortia, strategic } \\
\text { alliance, clusters, spin-off } \\
\text { and spin-out companies, } \\
\text { etc.) }\end{array}$ \\
\hline & $\begin{array}{l}\text { Efficiently functioning } \\
\text { university using modern } \\
\text { university management } \\
\text { methods }\end{array}$ & $\begin{array}{l}\text { Implementation of the } \\
\text { university strategic } \\
\text { management system }\end{array}$ & $\begin{array}{l}\text { Development and } \\
\text { implementation of an } \\
\text { intellectual property } \\
\text { management system }\end{array}$ \\
\hline \multirow{4}{*}{ 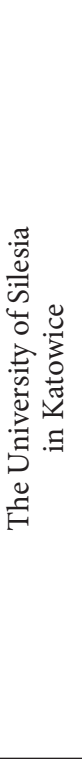 } & $\begin{array}{l}\text { Strong research teams } \\
\text { and world-class research }\end{array}$ & $\begin{array}{l}\text { Development and } \\
\text { implementation of the } \\
\text { system of intellectual } \\
\text { property protection and } \\
\text { copyright management }\end{array}$ & $\begin{array}{l}\text { Development of internal } \\
\text { legal acts regulating } \\
\text { the use of intellectual } \\
\text { property }\end{array}$ \\
\hline & $\begin{array}{l}\text { Innovative education } \\
\text { and modern teaching } \\
\text { offer }\end{array}$ & $\begin{array}{l}\text { Openness and } \\
\text { innovation in the field } \\
\text { of education }\end{array}$ & $\begin{array}{l}\text { Introducing content } \\
\text { related to innovation } \\
\text { and entrepreneurship, } \\
\text { intellectual property and } \\
\text { labour market to study } \\
\text { programs }\end{array}$ \\
\hline & $\begin{array}{l}\text { Active cooperation of } \\
\text { the university with the } \\
\text { environment }\end{array}$ & $\begin{array}{l}\text { Constant cooperation } \\
\text { with regional institutions } \\
\text { of the university on a } \\
\text { regional, national and } \\
\text { international scale }\end{array}$ & $\begin{array}{l}\text { Supporting academic } \\
\text { entrepreneurship and } \\
\text { the development of } \\
\text { the Academic Business } \\
\text { Incubator }\end{array}$ \\
\hline & $\begin{array}{l}\text { System management of } \\
\text { the university }\end{array}$ & $\begin{array}{l}\text { Introducing systemic, } \\
\text { efficient and modern } \\
\text { management of the } \\
\text { university }\end{array}$ & $\begin{array}{l}\text { Promotion of academic } \\
\text { entrepreneurship }\end{array}$ \\
\hline \multirow{3}{*}{ 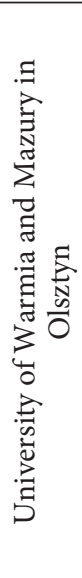 } & $\begin{array}{l}\text { Attractive educational } \\
\text { offer and high level of } \\
\text { education }\end{array}$ & $\begin{array}{l}\text { Improving the quality } \\
\text { of teaching }\end{array}$ & $\begin{array}{l}\text { Extension of organi- } \\
\text { sational and teaching } \\
\text { opportunities to develop } \\
\text { entrepreneurial interests } \\
\text { in students }\end{array}$ \\
\hline & $\begin{array}{l}\text { Internationalisation } \\
\text { and the world level } \\
\text { of academic research }\end{array}$ & $\begin{array}{l}\text { Creating conditions for } \\
\text { the development } \\
\text { of academic research }\end{array}$ & $\begin{array}{l}\text { Ensuring intellectual } \\
\text { protection of research } \\
\text { results }\end{array}$ \\
\hline & $\begin{array}{l}\text { Active participation in } \\
\text { the socio-economic life } \\
\text { of the region and the } \\
\text { country }\end{array}$ & $\begin{array}{l}\text { Technology transfer } \\
\text { and commercialisation } \\
\text { of research results }\end{array}$ & $\begin{array}{l}\text { Establishment } \\
\text { and development } \\
\text { of the business } \\
\text { entrepreneurship } \\
\text { incubator and } \\
\text { supporting the creation } \\
\text { of start-up and spin-off } \\
\text { companies }\end{array}$ \\
\hline
\end{tabular}




\begin{tabular}{|l|l|l|l|}
\hline & $\begin{array}{l}\text { Strengthening } \\
\text { cooperation with } \\
\text { the socio-economic } \\
\text { environment }\end{array}$ & $\begin{array}{l}\text { Cooperation with } \\
\text { business entities }\end{array}$ & $\begin{array}{l}\text { Implementation } \\
\text { of the system of } \\
\text { support for academic } \\
\text { staff in activities } \\
\text { related to academic } \\
\text { entrepreneurship, } \\
\text { strengthening activities } \\
\text { of the Academic } \\
\text { Business Incubator }\end{array}$ \\
\hline
\end{tabular}

Source: based on the development strategies of universities available on their websites

Among the strategic goals of the universities, no direct references to academic entrepreneurship were found. Explicit references to these issues, however, can be found at the level of operational objectives and activities/tasks defined in the development strategies. Although the presented strategic goals do not have such a direct reference to the concept, Table 2 presents them to show the location of those at lower levels in relation to general strategic goals. Academic entrepreneurship is generally included in strategic goals referring to cooperation with the environment (confirmed by eight out of nine analysed documents).

The direct references to the studied issues are demonstrated at the operational objective level in the analysed strategies, i.e. (1) empowering students, creating active and entrepreneurial attitudes (University of Opole), and (2) creating active and entrepreneurial attitudes in students (University of Rzeszów). These operational objectives relate to shaping the entrepreneurial attitudes of students. At this level, issues of intellectual property management are more often present mainly concerning the development and implementation of an intellectual property protection system and copyright management (Adam Mickiewicz University in Poznań, Jan Kochanowski University in Kielce, University of Opole, the University of Silesia in Katowice).

Most entries regarding academic entrepreneurship can be found at the third, lowest level in the hierarchy of goals, i.e. at the level referred to as activities/tasks. Four groups might be identified: (1) the process of establishing companies (spin-offs or spin-outs), (2) development of educational programs and entrepreneurial attitudes among students and academics, (3) creating institutions and programs that support setting up companies, and (4) intellectual property management (intellectual property protection). Information on the number of universities in whose strategies the above four groups appeared is presented in Table 3.

In the strategies of two universities (University of Rzeszów, University of Warmia and Mazury in Olsztyn), the lowest level includes provisions regarding the process of establishing companies (spin-offs or spin-outs) and the need to support such activities is noticeable. The issue of the development of educational programs and entrepreneurial attitudes is found in the strategies of all universities. This type of activity seems to be of the greatest importance. Creating institutions (e.g. business/entrepreneurial incubators) and programs that support setting up companies is also often present: seven out of nine have included this in their documents. References to issues of intellectual property management are also noticeable (six documents). 
Table 3. Universities in whose strategies academic entrepreneurship appear

\begin{tabular}{|l|c|c|c|c|}
\hline \multicolumn{1}{|c|}{$\begin{array}{c}\text { Strategy elements: } \\
\text { Academic entrepreneurship as: }\end{array}$} & $\begin{array}{c}\text { Mission } \\
\text { statements }\end{array}$ & $\begin{array}{c}\text { Strategic } \\
\text { goals }\end{array}$ & $\begin{array}{c}\text { Operational } \\
\text { goals }\end{array}$ & $\begin{array}{c}\text { Activities/ } \\
\text { Tasks }\end{array}$ \\
\hline $\begin{array}{l}\text { The process of establishing } \\
\text { companies }\end{array}$ & - & - & - & 2 \\
\hline University entrepreneurship & 1 & & & \\
\hline $\begin{array}{l}\text { Development of educational } \\
\text { programs and entrepreneurial } \\
\text { attitudes }\end{array}$ & 2 & - & 2 & 7 \\
\hline $\begin{array}{l}\text { Creating institutions and programs } \\
\text { that support setting up companies }\end{array}$ & - & - & - & 7 \\
\hline Intellectual property management & - & - & 4 & 6 \\
\hline $\begin{array}{l}\text { Entrepreneurial university } \\
\text { management }\end{array}$ & - & - & - & - \\
\hline
\end{tabular}

Source: compiled by the author

\section{Conclusions and summary}

In this paper, the author has attempted to answer the following research question: "How is academic entrepreneurship present in the development strategies of Polish universities?" A broad approach to the perception of the concept was adopted. The response given in the article was presented in reference to universities' mission statements, strategic and operational goals and activities/tasks defined in the development strategies.

In the universities' mission statements, academic entrepreneurship is understood as university entrepreneurship and as the development of educational programs and entrepreneurial attitudes among students and academics. No direct references to the academic entrepreneurship are present at the level of the strategic goals while direct references scarcely appear at the operational objectives level in the analysed strategies and relate to shaping the entrepreneurial attitudes of students and intellectual property management.

Most entries regarding academic entrepreneurship can be found at the lowest level named as activities/tasks. These concern the process of establishing companies, the development of educational programs and entrepreneurial attitudes among students and academics, creating institutions and programs that support the setting up of companies and intellectual property management. It is worth mentioning that the issue of the development of educational programs and entrepreneurial attitudes is found in the strategies of all universities.

Considering the facts that: (1) academic entrepreneurship issues are present only in nine of 18 university strategies, (2) only in the case of three universities their mission statements contained direct references, (3) there are no direct references at the level of the strategic goals of the universities, and (4) the subject of entrepreneurial university management was not included at all, it can be concluded that university authorities do not perceive academic entrepreneurship as a goal of the utmost importance and only to a small extent see the need to develop this concept by taking it into account in development strategies. This conclusion is in line with the opinion of Banerski et al. (2009), according to which in Poland, higher education institutions are still perceived as entities not particularly interested in the fact that students and academics can develop their own business. 
How to change this state of affairs? Academic entrepreneurship may be stimulated through a change of mindset of students and researchers, and a more friendly "climate" which should be created in the universities (Banerski et al., 2009). This means that the boosting of entrepreneurship requires an active role of the university in this process. For example, different innovative tools for academic entrepreneurship might be implemented, including institutional forms of support (academic enterprise incubators, technology transfer centres, science and technology parks) and support programs directed to students and academics (Makieła, 2017). Besides, academic entrepreneurship also requires cooperation with the external environment.

In the end, it can be agreed with Wawak (2012) that developing a strategy is not enough. In his opinion, it must be a realistic strategy, developed by competent strategists, which its creators will consistently implement. He also noted that it is necessary to correct a strategy if the circumstances require it (Wawak, 2012).

\section{References}

Banerski, G., Gryzik, A., Matusiak, K.B., Mażewska, M., Stawasz, E. (2009). Przedsiębiorczość akademicka (rozwój firm spin-off, spin-out) - zapotrzebowanie na szkolenia służące jej rozwojowi. Raport z badania. Warszawa: Polska Agencja Rozwoju Przedsiębiorczości.

Brendzel-Skowera K. (2014). Potencjał przedsiębiorczy uczelni na przykładzie Politechniki Częstochowskiej. Przegląd Organizacji, 12, 26-31.

Carlsson, B., Acs, Z.J., Audretsch, D.B., Braunerhjelm, P. (2009). Knowledge creation, entrepreneurship, and economic growth: a historical review. Industrial and Corporate Change, 18(6), 1193-1229.

Carree, M., Della Malva, A., Santarelli, E. (2014). The contribution of universities to growth: empirical evidence for Italy. The Journal of Technology Transfer, 39, 393-414.

Czakon, W. (2015). Rygor metodologiczny. W: W. Czakon (ed.), Podstawy metodologii badań w naukach o zarzadzaniu. Warszawa: Oficyna, 82-102.

Czernek, K. (2015). Wprowadzenie do badań jakościowych w naukach o zarządzaniu. W: W. Czakon (ed.), Podstawy metodologii badań w naukach o zarządzaniu. Warszawa: Oficyna, 167-188.

Dziedziczak-Foltyn, A. (2011). Strategie uczelniane - antycypacja, translacja czy pseudokonformizacja celów polityki rozwoju szkolnictwa wyższego? W: Zarządzanie szkoła wyższa. Dylematy i wyzwania. Gdańsk: Wyższa Szkoła Bankowa, 183-202.

European Commission. (2006). Implementing the Community Lisbon Program: Fostering entrepreneurial mindsets through education and learning. Communication from the Commission to the Council, the European Parliament, the European Economic and Social Committee and the Committee of the Regions. Brussels, COM (2006)33 final.

Griffin, R. W. (2014). Podstawy zarządzania organizacjami. Warszawa: Wydawnictwo Naukowe PWN SA.

Makieła, Z. (2017). Przedsiębiorczość i innowacyjność akademicka w Polsce. Przedsiębiorczość Edukacja [Entrepreneurship - Education], 13, 183-195.

Piotrowska-Piątek, A. (2015). Analiza strategii rozwoju szkół wyższych w Polsce. Organizacja i Zarządzanie, 2(30), 103-116.

Płaziak, M., Rachwał, T. (2015). „Przedsiębiorczy region” - zarys koncepcji w świetle analizy roli przedsiębiorczości w krajowej strategii rozwoju regionalnego. Przedsiębiorczość - Edukacja [Entrepreneurship - Education], 11, 37-49.

Poznańska, K. (2014). Przedsiębiorczość akademicka - cechy i znaczenie w gospodarce światowej i polskiej. W: T. Kraśnicka (ed.), Innowacyjność współczesnych organizacji. Kierunki i wyniki badań, czesść II. Katowice: Uniwersytet Ekonomiczny w Katowicach, 164-172. 
Romanowska, M. (2012). Metody badania strategii. Prace Naukowe Wałbrzyskiej Wyższej Szkoły Zarządzania i Przedsiębiorczości. Metody badań problemów zarządzania strategicznego, 17(1), 65-77.

Silverman, D. (2008). Prowadzenie badań jakościowych. Warszawa: Wydawnictwo Naukowe PWN.

Stoner, S.J.A.F., Freeman, R.E., Gilbert, D.R. Jr. (2001). Kierowanie. Warszawa: Polskie Wydawnictwo Ekonomiczne.

Strategia rozwoju szkolnictwa wyższego: 2010-2020. Projekt środowiskowy. (2009). Warszawa: Wydawnictwa Uniwersytetu Warszawskiego.

Szkoły wyższe i ich finanse w 2017 r. (2018). Warszawa - Gdańsk: Główny Urząd Statystyczny.

Ustawa z dnia 27 lipca 2005 Prawo o Szkolnictwie Wyższym. Dz.U. nr 164, poz. 1365, z późn. zm.

Vroom, V.H. (1960). The Effect Attitudes on Perception of Organisational Goals. Human Relations, 13, 229-249.

Wach, K. (2015). Przedsiębiorczość jako czynnik rozwoju społeczno-gospodarczego: przegląd literatury. Przedsiębiorczość - Edukacja, 11, 24-36.

Wawak, T. (2012). Jakość zarządzania w szkołach wyższych. Kraków: Wydawnictwo Uniwersytetu Jagiellońskiego.

Wawak, T. (2014). Strategie zarządzania i rozwoju uniwersytetów Krakowa. W: A. Stabryła, T. Małkus (ed.), Strategie zarządzania organizacjami w społeczeństwie informacyjnym. Kraków: Mfiles.pl, 33-55.

Woźnicki, J. (2010). Strategia rozwoju szkolnictwa wyższego: 2010-2020. Przedstawienie projektu środowiskowego. Nauka, 1, 97-114.

Zakrzewska-Bielawska, A. (2011). Relacje między strategia a strukturą organizacyjna w przedsiębiorstwach sektora wysokich technologii. Łódź: Wydawnictwo Politechniki Łódzkiej.

Marta Tutko, PhD. Author is an assistant professor at the Institute of Economics, Finance and Management, Faculty of Management and Social Communication, Jagiellonian University in Kraków, Poland. She is a graduate of the University of Economics in Cracow and the Jagiellonian University (she holds a PhD degree in economics in the discipline of Management). Her academic and research interests concern quality management, quality culture and management in higher education institutions. She is the Dean's Representative for Education Quality Improvement and Chairwoman of the Faculty Education Quality Improvement Commission.

ORCID: https://orcid.org/0000-0002-8359-8081

\section{Address:}

Uniwersytet Jagielloński w Krakowie

Wydział Zarządzania i Komunikacji Społecznej

Instytut Ekonomii, Finansów i Zarządzania

Katedra Zarządzania Jakością

ul. Prof. St. Łojasiewicza 4

30-348 Kraków, Poland

e-mail: marta.tutko@uj.edu.pl 